\title{
Efficiency of Premature Coffee Futures Market in Indonesia
}

\author{
Anis Erma Wulandari ${ }^{1 *} \quad$ Harianto $^{2} \quad$ Bustanul Arifin $^{3} \quad$ Heny Kuswanti Suwarsinah $^{1}$ \\ 1.School of Business Bogor Agricultural University, Jl. Pajajaran, Bogor 16151 \\ 2.Department of Agribusiness Faculty of Economics and Management, Bogor Agricultural University \\ Jl. Kamper, Wing 4 Level 5 Kampus IPB Dramaga Bogor 16680 \\ 3.University of Lampung \\ J1. Prof. Dr. Ir. Sumantri Brojonegoro No.1, Gedong Meneng, Rajabasa, Kota Bandar Lampung, Lampung 35145
}

\begin{abstract}
Coffee price risk emphasize the importance of futures markets existence as price risk management. This study examines whether the futures price may predict the spot price as the indicator of market efficiency using data of daily Arabica and Robusta coffee prices from 1172 trading days starting from January 2014 to June 2018. Analysis using Engel-Granger Cointegration and Error Correction Model (ECM) indicates the cointegration between coffee futures market and its spot market both in long term and also short term. Significant coefficient in futures and spot market respond to restore the equilibrium whenever there is some price discrepancy. Arabica spot price coefficient is lower than Arabica futures price which indicates that Arabica futures price have faster adjustment toward the disequilibrium and transmit information to spot market therefore price discovery in futures market. Analysis toward Robusta futures and spot market are also indicates the same phenomenon. Indonesia premature coffee market shows unique condition in which there is an arbitrage potential however the two market exhibits cointegration indicates the efficient market. Integrated market will perform risk transfer function and may however beneficial to hedgers, speculators and arbitrageurs in connecting the two markets. Further, the analysis result between onshore and offshore market with the same period of price information exhibits long term relationship. This confirms strong position of Indonesia coffee production information among other coffee producers for aggregate world coffee production.
\end{abstract}

Keywords: Coffee, commodity futures, cointegration, efficiency, spot market.

DOI: $10.7176 / \mathrm{EJBM} / 11-3-07$

\section{Introduction}

Indonesia is an agricultural country with agricultural activity which reached 7.6 million hectare of land used for commodity crop in 2016. Coffee crops itself reach 1.2 million hectares across 34 provinces in Indonesia and supports domestic consumption and export to various countries. Main coffee producers are located in Sumatera, Java, Bali, Nusa Tenggara, Kalimantan and Sulawesi which dominates 70 percent Indonesia coffee production. Indonesia export volume was relatively fluctuated within the last 10 years (2007-2017). Coffee export volume reached 321.400 metric ton in 2007 and increased to 346.400 metric ton in 2011. It was even reached 534.000 ton in 2013, however it's then declined in 2017 to 467.800 ton in 2017 (Dirjenbun, 2016) with coefficient of variance of 14.5 percent. Most of them were exported to United States, United Kingdom, Germany and Italy. Domestic consumption has shown increasing trend and showed 5.8 percent increasing number from 259.900 metric ton in 2015 to 276.000 metric ton back in 2017 (ICO 2017). Indonesia coffee production (recorded in 2017) was the $4^{\text {th }}$ largest in the world after Brazil, Vietnam and Columbia. The coffee production was relatively stagnant with the decreasing trend from 639.400 metric ton in 2015 to 637.500 metric ton in 2017. Indonesia produce higher number of Robusta compare to Arabica with the composition of approximately 80 percent of Arabica coffee against total domestic coffee production. Coffee contributes not only export revenue but also labor opportunity which reach 1.795 million smallholders farmer in 2016 although decrease in 2017 to 1.792 million householders (Dirjenbun, 2016) who were mostly smallholder farm and become the only one source of income for the farmer.

Coffee is one of the agricultural commodity which considered as a risky financial activity in which farmers are significantly affected by yield risk and output price risk (Walker and Ryan, 1990; Kurosaki, 1998). This is due to the seasonality of the agricultural commodity which mostly grown in certain temperate-zone country and have strong seasonal production patterns. As a result, the biological nature of crop production plays an important role in agricultural product price behavior (Schnepf, 2006). Coffee production is not only impacted by natural factors but also social and economic factors. It will not only depend on the climate condition and diseases but also cultivation method and post harvesting technology. Generally, coffee producers will be facing production risk and also market risk in the form of price fluctuation and market uncertainty. In coffee supply chain, not only farmer who have price risk exposure but also collector trader, exporter and processor of coffee product (Arifin, 2010). Price risk is effected not only by supply and demand but also affected by market mechanism in each level from the coffee farmer up to the coffee processor who demand large coffee supply. One of the price risk indicator may be seen through coffee price volatility and price level between the market along the supply chain. 
Putri et al. (2013) mentioned that farmer is a price taker which reflected on the unintegrated coffee market between farmer level both long and short term also coffee market in collector, cooperation and exporter level. Coffee price has certain spike behavior as shown in Figure 1 and 2. Both spot price volatility of coffee is plotted in standard deviation using 15 days of moving average numbers. Volatility of Robusta coffee was high by the end of 2014 until mid 2015 due to the impact of the decreasing of world coffee prices. It was impacted by natural factor (hard rainy season) in main coffee producer countries (Brazil, Vietnam and Indonesia). Indonesia spot prices is still found using offshore market prices as reference in price determination and therefore when the LIFFE (London International Financial Futures and Options Exchange) market price impacted by the aforementioned conditions, Robusta Lampung spot price as local reference was also impacted. Considering the seasonality which impacted by the weather, Indonesia was also experiencing decreasing number of Lampung Robusta export by 30 percent in 2015 while the demands captured with higher trend. This is also applied for Arabica coffee which using ICE Futures Coffee New York as reference.

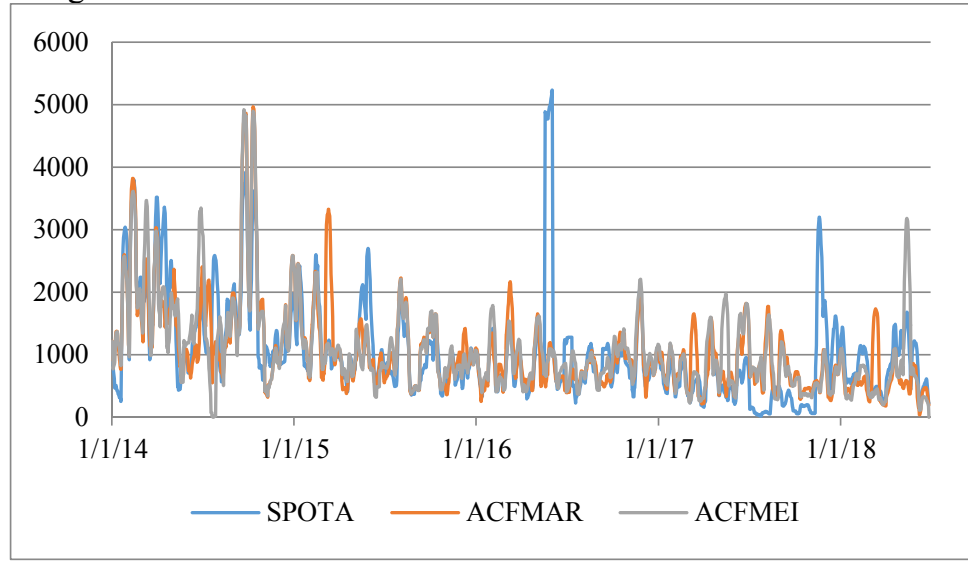

Figure 1. Arabica coffee price volatility

Futures market then has been introduced and established to provide price stability, reduce poverty and ensure growth to the economy. Bose (2007) mentioned that futures is also providing the investors an opportunity to hedge the risk of their positions in cash market. Hedging is the procedure of offsetting price risk in any cash market position by taking equal and opposite position in futures market. Traders use to buy or sell futures contract against the corresponding sale or buy of equivalent commodity to hedge the potential future price risk. On the other hand, futures market offers a wide range of contracts for a commodity. As a result, there is always flexibility of pricing for the traders. Thus, two major economic functions of a commodity futures market are price risk management and price discovery.

Futures market may provide selling option to the coffee producers should they are aware of the benefit and risk, have the access the liquidity and technology which provide ability for the coffee producer to access information in both markets. Futures market in Indonesia was introduced in 1997 after the issuance of Law No. 32 year 1997 and coffee futures was started to be actively traded in 2013 and require extra hard work to create the efficient futures market in this such premature conditions. In India, commodity futures markets have been in existence for more than a century. Their ability to meet the price risk management needs of producers and traders has created a compelling need for transforming them to highly sophisticated markets, where cutting-edge technology, wide variety of contracts, increasing awareness and participation of users together with tight regulatory framework, all work towards the ultimate aim of improving the market efficiency. Price discovery and price risk management are the twin functions which are used to measure the efficiency of futures market. The mechanism of price discovery aids in ascertaining the true price of an asset in the marketplace where a large number of buyers and sellers are interacting (Sharma and Malhotra 2013).

Small scale coffee producers in Indonesia have low in liquidity and limited access to financing stimulates farmers to choose the selling option which sells in spot markets rather than perform commodity storage and hedging in futures market. Coffee producers may have the cash faster without considering whether the price can cover their production cost. They may obtain the cash by selling in spot market and use for their daily live expenses also for continuing their production or harvesting process. Coffee spot price is actually available as reference by using certain spot market. Arabica coffee use Medan spot price as reference and Robusta use Lampung spot price as reference. The regulator assigns several contributors prior the spot price is published on the next day. Should the futures market well developed and the information flowing from futures to spot market, coffee producer may take the benefit and contribute selling decision to provide optimum income to the coffee producers. 


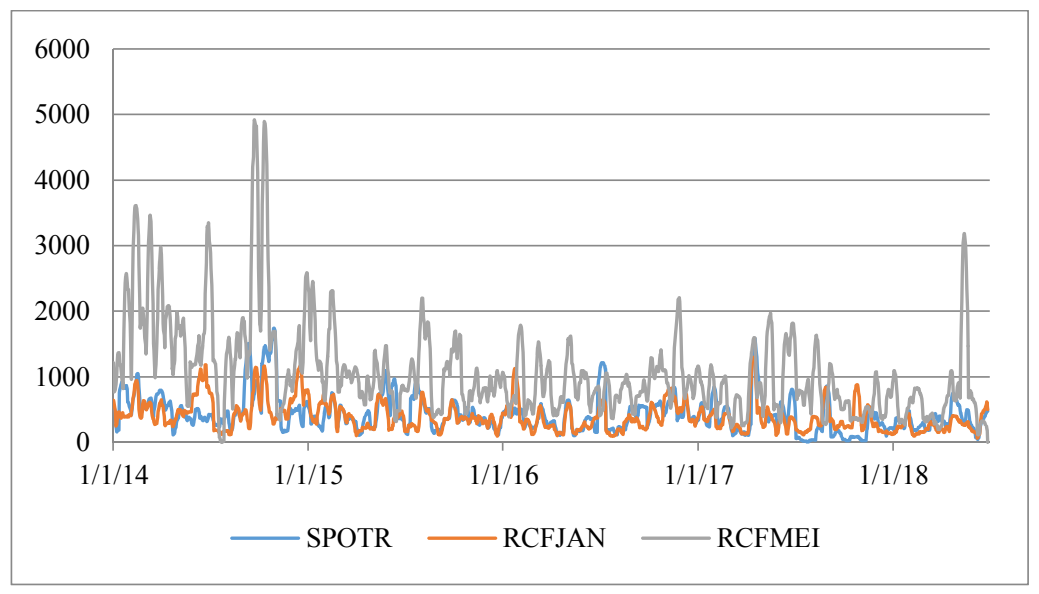

Figure 2. Volatility of Robusta coffee prices

Small scale coffee producers in Indonesia with low level of liquidity and limited access to financing stimulates farmers to choose the selling option whether they wish to sell directly to collector trader or spot markets, perform commodity storage and hedging in futures market. Coffee producers may have the cash faster without considering whether the price can cover their production cost. They may obtain the cash by selling to collector trader and use for their daily live expenses also for continuing their production or harvesting process. Small scale coffee producers in Indonesia with low level of liquidity and limited access to financing stimulates farmers to choose the selling option whether they wish to sell directly to collector trader or spot markets, perform commodity storage and hedging in futures market. Coffee producers may have the cash faster without considering whether the price can cover their production cost. They may obtain the cash by selling to collector trader and use for their daily live expenses also for continuing their production or harvesting process. Farmer will accept whatever price offered by the collector trader as they are unable to access price information due to their technical limitation. Several important issues for smallholder coffee production system in the context of the global value chain include low productivity, low quality of coffee bean, and low bargaining positions before the traders, coffee roasters, and exporters (Arifin 2010).

Should farmer may access the price information, they may use coffee spot price as their reference prior selling their stock. Arabica coffee use Medan spot price and Robusta use Lampung spot price as reference. The regulator assigns several contributors prior the spot price is published on the next day. Under well-developed futures market the information flows from futures to spot market and coffee producer may take the benefit and contribute selling decision to provide optimum income to the coffee producers in line with "Efficient Markets Hypothesis" [EMH]. Fama (1970) define EMH as markets in which asset prices always fully and instantaneously reflect all available information. The EMH describes an efficient market as one which consistently incorporates all information in determining prices. The three well-known assumptions of the EMH are: (1) that there are no transaction costs; (2) information is costlessly available to all market participants; and (3) the implications of current information for both the current price and distributions of future prices are accepted by all market participants. While in fact, the price information might be accessible by limited market participants and not easily available by other stakeholders who may require the information such as researcher and in specific, farmer who badly require the information.

Ajao (2012) mentioned if markets were efficient, futures prices would be unbiased predictors of future spot prices and a simple prediction model would suffice, but should the markets are not efficient such predictions cannot be accurately made. The relationship between the two markets is very critical to be examined whether futures prices may actually predict the spot market and reflected in Indonesia coffee futures market considering the very premature market condition. Futures prices give necessary indications to producers and consumers about the likely future ready price and demand and supply conditions of the commodity traded.

Instability of commodity prices has brought the interest to futures market considering the function as the hedging instrument and tools to mitigate the risk vulnerability. Lence (2009) mentioned that risk vulnerability is the most important matter faced by the commodity producers in developing and developed countries. Furthermore, this new interest has expanded the utilization of futures market and food security option as it has been proposed as one of price volatility management in importing countries (in this case for other agricultural commodity i.e wheat). Commercial participants (for wheat market) use futures contracts to hedge their crops or inventories against the risk of fluctuating prices, e.g., processors of agricultural commodities, who need to obtain raw materials, would buy futures contracts to guard against future price rises. If prices rise (i.e., both cash and futures prices), then they use the increased value of the futures contract to offset the higher cost of the physical quantities they need to purchase. (Sarris et al. 2011 in Revoredo-Giha and Zuppiroli 2013). Hence, futures price 
is worth to be considered as one of hedging instrument should the analysis confirms that futures price may actually influence the spot market or plays dominant role over the spot market not only for exporting countries like Indonesia but also importing countries in general to cover their stock price level. Pertiwi (2016) confirmed result of analysis of coffee price traded in futures exchange and its spot price indicate that the Arabica coffee and Robusta coffee commodity markets has a high level of price convergence. The implication, market participants or investors still choose to do hedging activities because the utility of futures contracts as a hedge has been effective. Few studies on commodity futures have been performed in Indonesia. Maulida et al. (2018) also confirmed similar that cocoa trading in futures market reflects efficient market and contained risk premium therefore hedging in futures market may be considered as sufficient in covering the price risk. Dewi et al. (2011) tested the Olein trading in Jakarta Futures Exchange and Wibowo (2017) also tested the hedging effectiveness of cocoa and coffee. More study is required to enrich research in futures market.

\section{Literature Review}

Mckenzie and Holt (1998) research results indicate that the live cattle, live hogs, corn and soybean meal futures markets are both efficient and unbiased in the long-run. These results suggest that in the long-run, risk premia do not exist in these markets. There is evidence that the iced broiler futures market is biased in the long-run. Shortrun inefficiencies were found exist in each market in the short-run. The iced broiler market exhibited short-run inefficiency even allowing for the possible existence of a constant risk premia. There was no evidence of a time varying risk premia in the live hogs and soybean markets to explain these short-run inefficiencies. There was some indication that a short-run time varying risk premia may have existed for live cattle and corn over the sample period.

Mattos and Garcia (2004), in their study of coffee, live cattle and sugar contracts in Brazilian Exchange, have pointed out that highly active contracts of coffee and live cattle have efficient futures market; however, even the thinly traded sugar contract also demonstrated some cointegration, wherein futures prices were leading the spot prices. Sharma and Malhotra (2013) studied the efficiency of guar seed futures market in India and observed a long-term relationship between the spot and futures markets. It was found that in the short run, the futures market was leading the spot market. Fortenbery and Zapata (1997) analyzed the relationship between the futures and cash prices of cheddar cheese in Wisconsin using cointegration. This study failed to find any longrun relationship between the futures and cash markets. However, they concluded that the absence of such relationship could be due to the fact that the cheddar cheese market was relatively new and was yet to gain sufficient trading experience. Jian and Leatham (1999) studied the price discovery function of wheat futures and cash markets separately in USA. They found a long-term equilibrium relationship among the futures markets and that the futures markets provided informed prices that cannot be embodied in the cash market.

Kumar (2004) carried out an early study on the futures prices of five commodities, namely, castor seed, cotton, groundnut oil, guar and pepper. He concluded that the futures markets were not efficient in predicting the futures spot prices and the markets were not well integrated. This study will also discuss the forward pricing function of futures markets that has been extensively researched and debated by economists for many years, yet the ability of futures markets to perform this function has never been compared across different supply and demand conditions. One of the implications of the theory of storage (Kaldor (1939), Working (1948), Brennan (1958) and Telser (1958)) is that futures prices can be expected to perform their forward price discovery role with different degrees of effectiveness depending on the level of inventory and demand for a commodity.

Fortenbery and Zapata (2004) examine the relationship between the New York coffee futures market and cash markets in two Latin American LDCs. The authors find that the futures market in New York acts as a center for price discovery and futures contracts in New York may offer hedging opportunities for coffee sector participants in South America. However, it is also found that to do so may only be risk-efficient over relatively long time horizons. Mohan and Love (2004) test London and New York coffee futures markets for efficiency. Coffee futures markets are found to be inefficient in terms of predicting subsequent spot prices. Rather than predicting spot prices futures prices appear to adapt to prevailing spot prices. Yang et al. (2001) observed better performance of storable commodities than non-storable commodities in price discovery. However, asset storability may not necessarily affect long-run relationship between futures and spot markets. Though futures markets are useful in predicting spot prices, there may be a bias in the magnitude of estimates.

\section{Research Design}

Data series of futures and prices are used in this study to identify price volatility and relationship between the two markets. Data consist of 1172 trading days starting from January 2014 to June 2018. Futures prices refer to the coffee contract prices traded in Jakarta Futures Exchange (JFX) covers all month of contract (delivery). Spot prices refers to certain spot market in Indonesia and include the offshore futures market price as reference for price determination with the same period while offshore futures contract price refers to data series issued by Indonesia Commodity Futures Supervisory Body (Bappebti). 
Table 1. Definition of variables

\begin{tabular}{|l|l|}
\hline \multicolumn{1}{|c|}{ Variables } & \multicolumn{1}{c|}{ Description } \\
\hline $\begin{array}{l}\text { Arabica spot price } \\
\text { (SPOTA) }\end{array}$ & $\begin{array}{l}\text { Applicable price from Medan spot market. Local spot price determines from } \\
\text { certain formula and use offshore futures price as reference. }\end{array}$ \\
\hline $\begin{array}{l}\text { Robusta spot price } \\
\text { (SPOTR) }\end{array}$ & $\begin{array}{l}\text { Applicable price from Lampung spot market with equal condition with Arabica } \\
\text { spot price. }\end{array}$ \\
\hline Arabica futures price & $\begin{array}{l}\text { Settlement price of Arabica futures contract price (ACF) with several delivery } \\
\text { date of March, May, July, September and December }\end{array}$ \\
\hline Robusta futures price & $\begin{array}{l}\text { Settlement price of Robusta futures contract price (RCF) with several delivery } \\
\text { date of January, March, May, July September and November }\end{array}$ \\
\hline ACF & Arabica Commodity Futures \\
\hline RCF & Robusta Commodity Futures \\
\hline Inflation (INF) & Consumer price index on month basis calculation. \\
\hline Interest rate (INT) & Interest rate reference issued by Bank Indonesia \\
\hline Exchange rate (FX) & Exchange rate of Indonesian Rupiah to US Dollar \\
\hline $\begin{array}{l}\text { Arabica futures price first } \\
\text { delivery (FUTAD1) }\end{array}$ & Futures prices of Arabica coffee refer to ICE New York with delivery of March \\
\hline $\begin{array}{l}\text { Arabica futures price } \\
\text { second delivery (FUTAD2) }\end{array}$ & $\begin{array}{l}\text { Futures prices of Arabica coffee refer to ICE Futures New York with several } \\
\text { delivery other than March (September and December) }\end{array}$ \\
\hline $\begin{array}{l}\text { Robusta futures price first } \\
\text { delivery (FUTRD1) }\end{array}$ & $\begin{array}{l}\text { Futures price of Robusta coffee refer to London Robusta Coffee Futures (LIFFE- } \\
\text { London International Financial Futures and Options Exchange) with delivery of } \\
\text { January }\end{array}$ \\
\hline $\begin{array}{l}\text { Robusta futures price first } \\
\text { delivery (FUTRD2) }\end{array}$ & $\begin{array}{l}\text { Futures price of Robusta coffee refer to London Robusta Coffee Futures (LIFFE) } \\
\text { with delivery other than January (September and November) }\end{array}$ \\
\hline
\end{tabular}

\subsection{Unit root test for stationarity test}

Futures and spot prices of coffee Arabica and Robusta are first examined for stationary with Augmented Dickey Fuller (ADF) unit root test (Dickey and Fuller 1979). Should the data series of prices be not stationary, then first difference shall be taken which eliminates unit root problem and the analysis is done on the differenced series. ADF unit root is tested using the following:

$$
\Delta X_{t}=b_{0}+b_{1} X_{t-1}+\sum_{t-1}^{T} b_{i} \Delta X_{t-i}+\varepsilon_{t}
$$

$X_{t}$ is the first order or difference of the variable, $\Delta X_{t}=X_{t}-X_{t-1}$ is spot price and futures price variable, $\mathrm{T}$ is deviation white noise, $b_{0}$ and $b_{i}$ is the estimated coefficient and $\varepsilon_{t}$ is white noise. Hypothesis of the stationary test is null hypothesis of non-stationary and alternative hypothesis is no unit root or stationary. We will reject null hypotheses should the p-value is less than 5 percent that is, series is non-stationary or series has unit root. So we will accept the alternative hypotheses, that is, series is stationary and there is no unit root.

\subsection{Cointegration between futures and spot market}

Long term relationship is discovered if the two variables are stationary. However, in the case of noncointegration shows that the data series has no long term relationship. Cointegration analysis used in this study is Engle and Granger cointegration (1987). ADF test toward the regression may be performed with several model as follows with null hypothesis is have unit root problem, non-stationary.

3.2.1 Estimate the long-term equilibrium

Stationary test shall be performed using the Augmented Dickey-Fuller (ADF) test upon the ordinary least square (OLS) regression. This what being called as a two-step procedure for cointegration analysis.

$$
P_{t}=\delta_{0}+\delta P^{\prime}+\varepsilon_{t}
$$

$P_{t}, P_{t}^{\prime} \quad:$ spot/futures coffee price in time t, $P_{t} \neq P_{t}^{\prime}$. Should the $\mathrm{P}_{\mathrm{t}}$ is non stationary then $\mathrm{P}_{\mathrm{t}}{ }^{\prime}$ or $\varepsilon_{t}$ or both shall be non-stationary. If $\varepsilon_{t}$ stationary then $P_{t}$ and $P_{t}^{\prime}$ are cointegrated.

The OLS residuals measure of disequilibrium:

$$
\varepsilon_{t}=\Delta P_{(j) t}-\beta_{0}-\beta_{1} \Delta P_{(j)(t-i)}
$$

A test of cointegration is a test of whether $\varepsilon_{t}$ is stationary. This is determined by ADF tests on the residuals, with the MacKinnon (1991) critical values adjusted for the number of variables. 


\subsubsection{Error Correction Model}

Should the futures and spot price be cointegrated, and thus a long-run stable relation can be expected between them. The cointegration between spot and futures prices provides support for analyzing short-run dynamics between the two prices by estimating the error correction model (ECM). ECM helps in identifying the market that contributes to the price discovery process and the direction of causality between futures and spot prices. Ghosh (1993), Lien and Luo (1994) and Lien (1996) argued that if the two price series are found to be cointegrated, then there exist valid error correction representations of the price series that includes short-term dynamics and long- run information. Granger (1986) states that if two variables are I(1) and cointegrated, there must be causality in at least one direction. A bidirectional causality is also possible. This is due to the error correction mechanism between the two series that keeps bringing them back to equilibrium at regular intervals.

After the long-run relationship has been established between spot and futures prices, the next step is to examine the short-run dynamics of the relation using the ECM with the following equation:

$$
\begin{gathered}
\Delta F_{t}=\alpha_{f}+\lambda_{f} e_{t-1}+\sum_{i=1}^{r} \lambda_{f, i} \Delta f_{t-i}+\sum_{i=1}^{r} \omega_{s, i} \Delta S_{t-i}+\varepsilon_{f t} \\
\Delta S_{t}=\alpha_{s}+\lambda_{s} e_{t-1}+\sum_{i=1}^{r} \lambda_{s, i} \Delta s_{t-i}+\sum_{i=1}^{r} \omega_{s, i} \Delta f_{t-i}+\varepsilon_{s t}
\end{gathered}
$$

In the above equations, $e_{t-1}$ is the equilibrium error which measures how the dependent variable adjusts to the previous period deviation from the equilibrium error. In other words, whenever there is some noise in the market which creates disequilibrium in spot and futures prices, the market which reacts first to the news helps in bringing back equilibrium. The coefficients of $e_{t-1}$ is $\lambda_{s}$ and $\lambda_{f}$, determine the speed of error correction. If $\lambda_{f}$ is statistically different from zero, then current periods' change in futures prices respond to last periods' deviation from long-run equilibrium, and in the same manner if $\lambda_{s}$ is statistically different from zero, then current periods' change in spot prices responds to last periods' deviation from long-run equilibrium by OLS as this equation has only $\mathrm{I}(0)$ variables, standard hypothesis testing using $\mathrm{t}$ ratios and diagnostic testing of the error term is appropriate. The adjustment coefficient a must be negative. The condition on the error correction term, $p$-value and t-statistic shall be satisfied to reject $H_{0}$ which in this stage market is inefficient and therefore accept $H_{1}$ or market is efficient.

\subsection{Test of Forward Price Discovery}

Several studies suggest that futures markets play a critical role in price discovery for the underlying spot market (Lien and Tse, 2000). This price discovery function implies prices in the futures and spot markets are systematically related in the short run and/or in the long run. In the cointegration framework, the price discovery function implies the presence of an equilibrium relation binding the two prices together. If a departure from equilibrium occurs, prices in one or both markets should adjust to correct the disparity (Mahalik et al. 2014). Further, analysis of forward and price discovery is performed. This analysis is adopted from Canter (1999) that test of forward discovery function of futures market can be divided into two categories: those that test whether futures prices are unbiased forecast of future spot prices, and those that compare the forecast information in futures prices to that of current spot prices, economic forecast or commercial forecast. The theory that futures prices are equivalent to expected spot prices and are those unbiased forecast can be expressed mathematically as follows:

$$
E\left(S_{T}-F_{t, T} \mid \phi_{t}\right)=0
$$

where $S_{T}$ is the spot price at time T, $F_{t, T}$ is the futures price at time $\mathrm{t}$ for delivery at time T, and $\phi_{t}$ is the information set at time $t$. This theoritical relationship is most commonly tested using the following regression equation which, for exposiitonal purposes, we will call the classic unbiasedness test:

$$
S_{T}=\alpha+\beta F_{t, T}+\epsilon_{t}
$$

Conclusion from this test are rather weak with regards to forward price discovery. It is possible that the hypothesis of $\alpha=0$ dan $\beta=1$ may be accepted, even though an alternative hypothesis of $\alpha=1$ and $\beta=0$ cannot be rejected because of large standard error. Thus, a finding that $\alpha>0$ and $\beta<0$ does not necessarily imply that futures prices are biased forecast of futures spot prices. It's possible that the result instead is casued by overlapping data, a stochastic trend in a cost - of-carry, or correlation between the independent variable and previous error terms.

\section{Empirical Result}

\subsection{Indonesia Coffee Price Information}

Arabica coffee price volatility within 2014-2018 are reflected by the coefficient of variation (CV) of 10.9 percent with the prices ranging between IDR54,312 (the lowest) and IDR 69,170 (the highest) per kg. Arabica coffee price highest fluctuation within the last 4 years was occurred in 2014 with coefficient of variation of 13.3 percent and still reflected with high coefficient of variation of 11.4 percent in 2015 . This was impacted by global factor i.e. harvesting failure in Brazil in 2014 which impacting the low volume of coffee stock in the market and many 
sellers tried to fulfill market expectation by selling the coffee stock and expect that coffee supply will be sufficient in the next harvesting period. The impact was still occurred until 2015 (Bappebti 2015).

Table 2. Statistic descriptive of Arabica spot prices ${ }^{\mathrm{a}}$

\begin{tabular}{|c|c|c|c|c|c|}
\hline Year & Min & Max & Mean & SD $^{c}$ & $\mathrm{CV}$ \\
\hline 2014 & 46989 & 69170 & 46989 & 5901 & $0.133^{b}$ \\
\hline 2015 & 53998 & 59741 & 53998 & 5858 & 0.114 \\
\hline 2016 & 54659 & 63117 & 54659 & 5834 & 0.111 \\
\hline 2017 & 56585 & 60360 & 56585 & 5814 & 0.106 \\
\hline 2018 & 57703 & 54116 & 57703 & 5796 & 0.103 \\
\hline 2014-2018 & 54312 & 69170 & 54312 & 5776 & 0.109 \\
\hline
\end{tabular}

Arabica coffee price discovered to be more fluctuated compare to Robusta. This is due to the production composition whereas the Arabica coffee has smaller volume of production compare to Robusta and market expectation toward Arabica coffee is lower than Robusta which causing demand to Robusta is higher after market loss Arabica coffee stock considering the substitution effect of the two coffees (Nicholson and Snyder 2008). The coefficient of variation of Robusta coffee spot price between 2014 to 2018 lied in 7.8 percent while Arabica 10.9 percent in the same period. The same factor found impacting this price movement. As the biggest producing country in the world, Brazil contribute significant impact to the world coffee price movement. Brazil was experiencing harvesting failure due to high rain intensity which then causing failure in flowering process and declining the coffee production in 2014 and the impact was continued until 2015.

Table 3. Statistic descriptive of Robusta spot prices ${ }^{\mathrm{a}}$

\begin{tabular}{|c|c|c|c|c|c|}
\hline Year & Min & Max & Mean & SD $^{\mathbf{c}}$ & CV \\
\hline 2014 & 17033 & 26940 & 20085 & 1744 & 0,087 \\
2015 & 17198 & 22778 & 18914 & 1742 & $0,092^{\mathrm{b}}$ \\
2016 & 15258 & 26817 & 21650 & 1734 & 0,080 \\
2017 & 22087 & 27465 & 25056 & 1731 & 0,069 \\
2018 & 24277 & 24277 & 25414 & 1728 & 0,068 \\
$2014-2018$ & 15258 & 27465 & 22130 & 1726 & 0,078 \\
\hline
\end{tabular}

Price risk mitigation of spot market may be hedged through taking position in futures market. Various deliveries are set in futures market and provide ability for the market participants to choose which delivery best for them to hedge their position either sell or buy position for coffee producer or processor. Arabica coffee futures contract (ACF) has 5 deliveries while Robusta coffee futures contract has 6 deliveries which may align with the harvesting period or buying season on the coffee consumer/processor. Arabica futures contract prices lied between IDR57,500 in minimum and maximum of IDR88,700 while Robusta coffee futures price ranging between IDR18,020 in minimum and maximum of IDR 31,010 per $\mathrm{kg}$. As shown in Table 3 contract with delivery of September hold highest coefficient of variation ( 8.4 percent) and followed by contract delivery of March (8.0 percent). As coffee is very dependent on natural and harvesting season, March delivery reflects market demand just before the harvesting period started and September delivery exhibits market demand by end of the harvesting season.

Table 4. Statistic descriptive of Arabica futures contract (ACF) ${ }^{\mathrm{d}}$

\begin{tabular}{|c|c|c|c|c|c|}
\hline Delivery month $^{\mathbf{e}}$ & Min & Max & Mean & SD $^{\mathbf{f}}$ & $\mathbf{C V}$ \\
\hline MAR & 59100 & 87800 & 68505 & 5475 & 0,080 \\
MEI & 59600 & 88350 & 68457 & 5331 & 0,078 \\
JUL & 59600 & 88450 & 68386 & 5273 & 0,077 \\
SEP & 57500 & 88750 & 68410 & 5776 & 0,084 \\
DEC & 60100 & 86800 & 68514 & 4850 & 0,071 \\
\hline
\end{tabular}

Highest coefficient of variation of RCF found in contract of September (0.054) and November (0.054) (nearly end of harvesting season and after harvesting period). While ACF contract coefficient of variation found highest in September (8.4 percent) nearly end of harvesting season and March (8.0) just before the harvesting season is started. Price movements are also affected by a number of extraordinary events such as foreign exchange price movements that are used as a reference and by extraordinary events in major coffee producing countries such as Brazil, Vietnam and Colombia, namely crop failure due to weather and also due to speculative transaction in offshore futures market (short covering) by market participants (Bappebti 2014). Robusta coffee futures contract prices lied between IDR18,020 in minimum and maximum of IDR 19,580 per $\mathrm{kg}$. Highest coefficient of variation shown in contract delivery of September and November with CV of 5.4 percent. This is confirming that these contract demand information of coffee production by the end of harvesting period and also 
the afterward. After harvesting period, the futures price reached the highest level of IDR31,010 per kg compare to other delivery period.

Table 5. Statistic descriptive of Robusta futures contract (RCF) ${ }^{\mathrm{d}}$

\begin{tabular}{|c|c|c|c|c|c|}
\hline Delivery month $^{\mathrm{e}}$ & Min & Max & Mean & SD $^{f}$ & $\mathrm{CV}$ \\
\hline JAN & 18610 & 31010 & 24808 & 1203 & 0,048 \\
\hline MAR & 18020 & 30810 & 24787 & 1179 & 0,048 \\
\hline MEI & 18550 & 30730 & 24748 & 1199 & 0,048 \\
\hline JUL & 18970 & 30870 & 24914 & 1234 & 0,050 \\
\hline SEP & 19310 & 30590 & 24875 & 1345 & 0,054 \\
\hline NOV & 19580 & 30640 & 24892 & 1339 & 0,054 \\
\hline
\end{tabular}

\subsection{Unit root test using $A D F$ test}

Before we test for cointegration of coffee futures and spot market, it is necessary to check the order of integration of the level variables. Therefore, unit root tests of each variable at their levels as well as first differences of non-stationary level variables were conducted. The result from Table 6 shows that all the variables are non-stationary at their levels. However, all the non-stationary variables are found to be stationary at their first differences, and therefore, are integrated of order one of coffee futures and spot markets. The stationary of spot prices, Arabica spot price (SPOTA) and Robusta spot price (SPOTR), also all futures prices of Arabica all delivery date (ACFMAR, ACFMEI, ACFJUL, ACFSEP, ACFDEC) and Robusta (RCFJAN, RCFMAR, RCFMEI, RCFJUL, RCFSEP, RCFNOV) including offshore futures prices (FUTAD1, FUTAD2, FUTRD1 and FUTRD2) have been checked by Augmented Dickey-Fuller (ADF) test. Stationary is required as regression using nonstationary series provides unreliable result. The first difference data (stationary data) as presented in Table 7 then use for further analysis as the ADF check as presented in Table 6 shows that data in level is have unit root problem or non-stationary. All variables then naming with D prior the identifies (DSPOTA, DSPOTR etc).

Table 6. Test of stationary through ADF test (in level)

\begin{tabular}{|c|c|c|c|c|c|c|c|c|c|}
\hline Variable & ACFMAR & ACFMEI & ACFJUL & ACFSEP & ACFDES & SPOTA & FUTAD1 & FUTAD2 & \\
\hline ADF Data & In level & In level & In level & In level & In level & In level & In level & In level & \\
t-stat & -3.745 & -3.702 & -3.636 & -3.747 & -3.839 & -5.886 & -2.455 & -2.196 & \\
p-values & 0.0574 & 0.0041 & 0.0051 & 0.0035 & 0.0025 & 0.0000 & 0.1268 & 0.2076 \\
Coefficient & -0.0087 & -0.0157 & -0.0155 & -0.0164 & -0.0175 & -0.0369 & -0.0075 & -0.0058 & \\
Decision & Accept $\mathrm{H}_{0}$ & Accept $\mathrm{H}_{0}$ & Accept $\mathrm{H}_{0}$ & Reject $\mathrm{H}_{0}$ & Reject $\mathrm{H}_{0}$ & Reject $\mathrm{H}_{0}$ & Accept $\mathrm{H}_{0}$ & Accept $\mathrm{H}_{0}$ & \\
\hline & RCFJAN & RCFMAR & RCFMEI & RCFJUL & RCFSEP & RCFNOV & SPOTR & FUTRD1 & FUTRD2 \\
\hline ADF Data & In level & In level & In level & In level & In level & In level & In level & In level & In level \\
t-stat & -2.970 & -2.904 & -3.245 & -2.806 & -2.823 & -2.773 & -2.637 & -2.317 & -2.093 \\
p-values & 0.0378 & 0.0449 & 0.0175 & 0.0574 & 0.0550 & 0.0623 & 0.0856 & 0.1666 & 0.2472 \\
Coefficient & -0.0101 & -0.0095 & -0.0120 & -0.0087 & -0.0086 & -0.0083 & -0.0088 & -0.0064 & -0.0053 \\
Decision & Accept $\mathrm{H}_{0}$ & Accept $\mathrm{H}_{0}$ & Reject $\mathrm{H}_{0}$ & Accept $\mathrm{H}_{0}$ & Accept $\mathrm{H}_{0}$ & Accept $\mathrm{H}_{0}$ & Accept $\mathrm{H}_{0}$ & Accept $\mathrm{H}_{0}$ & Accept $\mathrm{H}_{0}$
\end{tabular}

MacKinnon (1996) one-sided p-value 5\% significant level: -2.860; negative value of coefficient otherwise model is not valid; p-value is significant in 5\% significant level

Table 7. Test of stationary through ADF test (first different)

\begin{tabular}{|c|c|c|c|c|c|c|c|c|c|}
\hline Variable & ACFMAR & ACFMEI & ACFJUL & ACFSEP & ACFDES & SPOTA & FUTAD1 & FUTAD2 & \\
\hline ADF Data & $1^{\text {si }} \operatorname{diff}$ & $1^{\text {st }} \mathrm{diff}$ & $1^{\text {st }}$ diff & $1^{\text {st }}$ diff & $1^{\text {st }}$ diff & $1^{\text {st }} \operatorname{diff}$ & $1^{\text {st }}$ diff & $1^{\text {s }} \operatorname{diff}$ & \\
\hline t-stat & -41.500 & -41.607 & -42.606 & -43.369 & -43.202 & -52.991 & -43.871 & -43.480 & \\
\hline p-value & 0.000 & 0.000 & 0.000 & 0.000 & 0.000 & 0.000 & 0.000 & 0.000 & \\
\hline Coefficient & -1.0261 & -1.0285 & -1.0519 & -1.0696 & -1.0659 & -1.2640 & -1.0809 & -1.0719 & \\
\hline \multirow[t]{2}{*}{ Decision } & Reject $H_{0}$ & Reject $H_{0}$ & Reject $H_{0}$ & Reject $H_{0}$ & Reject $H_{0}$ & Reject $H_{0}$ & Reject $H_{0}$ & Reject $H_{0}$ & \\
\hline & RCFJAN & RCFMAR & RCFMEI & RCFJUL & RCFSEP & RCFNOV & SPOTR & FUTRD1 & FUTRD2 \\
\hline ADF Data & $1^{\text {st }}$ diff & $1^{\text {st }}$ diff & $1^{\text {st }}$ diff & $1^{\text {st }}$ diff & $1^{\text {st }}$ diff & $1^{\text {st }}$ diff & $1^{\text {st }}$ diff & $1^{\text {st }}$ diff & $1^{\$} \operatorname{diff}$ \\
\hline t-stat & -45.139 & -44.425 & -46.415 & -43.962 & -43.922 & -44.710 & -51.420 & -44.402 & -43.088 \\
\hline p-value & 0.000 & 0.000 & 0.000 & 0.000 & 0.000 & 0.000 & 0.000 & 0.000 & 0.000 \\
\hline Coefficient & -1.1064 & -1.0936 & -1.1409 & -1.0852 & -1.0842 & -1.1013 & -1.2360 & -1.0921 & -1.0612 \\
\hline Decision & Reject $H_{0}$ & Reject $H_{0}$ & Reject $H_{0}$ & Reject $H_{0}$ & Reject $H_{0}$ & Reject $H_{0}$ & Reject $H_{0}$ & Reject $H_{0}$ & Reject $H_{0}$ \\
\hline
\end{tabular}

MacKinnon (1996) one-sided p-value 5\% significant level: -2.860 ; negative value of coefficient otherwise model is not valid; $p$-value is significant in $5 \%$ significant level

Using the standard deviation of 15 days moving numbers, volatility of Arabica prices seen to have significant increasing trend (certain spike pattern) as shown in Figure 1. This may be impacted by the market structure which is number of buyer and seller of the traded commodity that contribute to the competitive prices, type of the trade commodity. For storable commodity, it may provide option for the producers to decide when 
and in what condition the commodity will be traded (Schnepf 2005) in Piot-Lepetit and M'barek (2011). Further, Schnepf mentioned that certain spike of prices may also be caused by non-existence of price information transparency and price manipulation then unable to be avoided. The presence of speculator in this stage is also suspected as the cause of unnatural price adjustment or prevent the prices reach their natural equilibrium. Other than speculator, several activities which causing the same impact is market collusion by several huge traders which then reduce the market prices. Hernandez and Torero (2009) mentioned that in general spot prices is more fluctuated compare to the futures which may be caused by the high price transparency in spot market however the same patter found between the two prices. However, the presence of speculator is not necessarily bringing negative impact to the market, refer to Holloway (2012), the result of his study indicate the possibility that speculators and futures traders potentially play appropriate roles in the futures markets by providing liquidity needed for the smooth functioning of the markets.

\subsection{Relationship between Futures and Spot Market}

Analysis result indicates the cointegration between spot and futures prices which shows the efficiency and reflect the long term equilibrium between the two series. In return, in the absence of cointegration indicates futures market provide limited information transmitted to spot market which reflect market inefficiency (Wang and Ke 2005, Ali dan Gupta 2011). As shown in Table 8, all deliveries exhibit stationary within the two markets. The test indicates that the coffee futures price is cointegrated with spot prices, indicating long-run equilibrium relationship between the two markets apply for both Arabica and Robusta. Chen and Lin (2004) mentioned that should there is any lack of cointegration may be due to nonstationary components of transportation and carrying costs, including factors like the interest rate, risk premiums, convenience yields and physical storage costs. However, as the coffee market shown the cointegration, then the aforementioned factors are less likely identified. The co-integration between spot and futures prices provides support for analyzing short-run dynamics between the two prices by estimating the error correction model (ECM).

Table 8 . Stationary test on the residual

\begin{tabular}{|c|c|c|c|c|c|c|c|c|}
\hline $\begin{array}{l}\text { ADF Test } \\
\text { Residual }\end{array}$ & $\begin{array}{c}\text { D(SPOTA) } \\
\text { D(ACFMAR) }\end{array}$ & $\begin{array}{c}\text { D(SPOTA) } \\
\text { D(ACFMEI) }\end{array}$ & $\begin{array}{c}\text { D(SPOTA) } \\
\text { D(ACFJUL) }\end{array}$ & $\begin{array}{c}\text { D(SPOTA) } \\
\text { D(ACFSEP) }\end{array}$ & $\begin{array}{c}\text { D(SPOTA) } \\
\text { D(ACFDES) }\end{array}$ & $\begin{array}{c}\text { D(SPOTA) } \\
\text { D(FUTAD1) }\end{array}$ & $\begin{array}{c}\text { D(SPOTA) } \\
\text { D(FUTAD2) }\end{array}$ & \\
\hline $\begin{array}{l}\text { t-stat } \\
\text { p-value } \\
\text { Decision } \\
\text { Conclusion }\end{array}$ & $\begin{array}{c}-37.747 \\
0.000 \\
\text { Reject } H_{0} \\
\text { Stationary }\end{array}$ & $\begin{array}{c}-40.686 \\
0.000 \\
\text { Reject } H_{0} \\
\text { Stationary }\end{array}$ & $\begin{array}{c}-39.587 \\
0.000 \\
\text { Reject } H_{0} \\
\text { Stationary }\end{array}$ & $\begin{array}{c}-48.795 \\
0.000 \\
\text { Reject } H_{0} \\
\text { Stationary }\end{array}$ & $\begin{array}{c}-50.086 \\
0.000 \\
\text { Reject } H_{0} \\
\text { Stationary }\end{array}$ & $\begin{array}{c}-59.828 \\
0.000 \\
\text { Reject } H_{0} \\
\text { Stationary }\end{array}$ & $\begin{array}{c}-60.919 \\
0.000 \\
\text { Reject } H_{0} \\
\text { Stationary }\end{array}$ & \\
\hline $\begin{array}{l}\text { ADF Test } \\
\text { Residual }\end{array}$ & $\begin{array}{c}\text { D(SPOTR) } \\
\text { D(RCFJAN) }\end{array}$ & $\begin{array}{c}\text { D(SPOTR) } \\
\text { D(RCFMAR) }\end{array}$ & $\begin{array}{c}\text { D(SPOTR) } \\
\text { D(RCFMEI) }\end{array}$ & $\begin{array}{c}\text { D(SPOTR) } \\
\text { D(RCFJUL) }\end{array}$ & $\begin{array}{c}\text { D(SPOTR) } \\
\text { D(RCFSEP) }\end{array}$ & $\begin{array}{c}\text { D(SPOTR) } \\
\text { D(RCFNOV) }\end{array}$ & $\begin{array}{c}\text { D(SPOTR) } \\
\text { D(FUTRD1) }\end{array}$ & $\begin{array}{c}\text { D(SPOTR) } \\
\text { D(FUTRD2) }\end{array}$ \\
\hline $\begin{array}{c}\text { t-stat } \\
\text { p-value } \\
\text { Decision } \\
\text { Conclusion }\end{array}$ & $\begin{array}{c}-54.168 \\
0.000 \\
\text { Reject } H_{0} \\
\text { Stationary }\end{array}$ & $\begin{array}{c}-51.960 \\
0.000 \\
\text { Reject } H_{0} \\
\text { Stationary }\end{array}$ & $\begin{array}{c}-53.469 \\
0.000 \\
\text { Reject } H_{0} \\
\text { Stationary }\end{array}$ & $\begin{array}{c}-54.842 \\
0.000 \\
\text { Reject } H_{0} \\
\text { Stationary }\end{array}$ & $\begin{array}{c}-54.138 \\
0.000 \\
\text { Reject } H_{0} \\
\text { Stationary }\end{array}$ & $\begin{array}{c}-24.26 \\
0.000 \\
\text { Reject } H_{0} \\
\text { Stationary }\end{array}$ & $\begin{array}{c}-56.502 \\
0.000 \\
\text { Reject } H_{0} \\
\text { Stationary }\end{array}$ & $\begin{array}{c}-56.863 \\
0.000 \\
\text { Reject } H_{0} \\
\text { Stationary }\end{array}$ \\
\hline
\end{tabular}

$\left[\mathrm{H}_{0}\right.$ : non-stationary]; MacKinnon (1996) one-sided 5\% critical value: $-2,860$; based on $\mathrm{t}$-stat $|\mathrm{t}|<\mid 5 \%$ critical value and $p$-value is significant in $5 \%$ significant value

ECM helps in identifying the market that contributes to the price discovery process and the direction of causality between futures and spot prices. As shown in Table 9, speed of adjustment coefficient is significant for both futures and spot market, indicating that both markets adjust to deviations from short-term equilibrium. The speed of adjustment coefficient of Arabica futures is higher in absolute terms compare to spot price, indicating a faster dissemination of information from futures than spot markets and therefore a price discovery in futures markets. The negative signs of coefficients indicate that both spot and futures prices are above their respective equilibrium value and would therefore fall in the next period to correct the equilibrium error. ECM analysis result for Robusta as shown in Table 10 also exhibits the same phenomenon which confirm that information flows from futures markets then transmit to spot market. 
Table 9. Analysis result of ECM between Arabica local futures and spot market

\begin{tabular}{|c|c|c|c|c|c|c|}
\hline \multicolumn{2}{|c|}{$\begin{array}{c}\text { Vector } \\
\text { Cointegration }\end{array}$} & $\begin{array}{c}\text { D(SPOTA) } \\
\text { D(ACFMAR) }\end{array}$ & $\begin{array}{c}\text { D(SPOTA) } \\
\text { D(ACFMEI) }\end{array}$ & $\begin{array}{c}\text { D(SPOTA) } \\
\text { D(ACFJUL) }\end{array}$ & $\begin{array}{c}\text { D(SPOTA) } \\
\text { D(ACFSEP) }\end{array}$ & $\begin{array}{c}\text { D(SPOTA) } \\
\text { D(ACFDES) }\end{array}$ \\
\hline $\begin{array}{c}\text { Coefficient } \\
\text { t-stat }\end{array}$ & D(SPOTA) & -0.3531 & -0.3300 & -0.3755 & -0.4742 & -0.3371 \\
p-value & -9.48 & -8.42 & -9.89 & -12.94 & -9.08 \\
SE & 0.000 & 0.000 & 0.000 & 0.000 & 0.000 \\
\hline Coefficient & D(ACF) & -0.4694 & -0.4188 & -0.4958 & -0.6999 & -0.4187 \\
t-stat & -9.86 & -8.94 & -10.41 & -14.45 & -9.20 \\
p-value & 0.000 & 0.000 & 0.000 & 0.000 & 0.000 \\
SE & 0.0476 & 0.0469 & 0.0476 & 0.0484 & 0.0455 \\
\hline \multicolumn{2}{|c|}{ Decision } & Reject $H_{0}$ & Reject $H_{0}$ & Reject $H_{0}$ & Reject $H_{0}$ & Reject $H_{0}$ \\
\hline
\end{tabular}

Negative value of coefficient which defines as Error Correction Term (ECT); based on $\mathrm{t}$-stat $|\mathrm{t}|<$

$15 \%$ critical value and p-value is significant in 5\% significant value

According to the ECM result, Indonesia coffee futures market deems to transmit information to spot market. Considering the premature market condition in which quite new coffee futures market, this become very important to confirm the cointegration for all deliveries which then beneficial to all market participants. Furth and whether there is potential of forward price discovery.

Table 10. Analysis result of ECM between Robusta local futures and spot market

\begin{tabular}{|c|c|c|c|c|c|c|c|}
\hline \multicolumn{2}{|c|}{$\begin{array}{c}\text { Vector } \\
\text { Cointegration }\end{array}$} & $\begin{array}{c}\text { D(SPOTR) } \\
\text { D(RCFJAN) }\end{array}$ & $\begin{array}{c}\text { D(SPOTR) } \\
\text { D(RCFMAR) }\end{array}$ & $\begin{array}{c}\text { D(SPOTR) } \\
\text { D(RCFMEI) }\end{array}$ & $\begin{array}{c}\text { D(SPOTR) } \\
\text { D(RCFJUL) }\end{array}$ & $\begin{array}{c}\text { D(SPOTR) } \\
\text { D(RCFSEP) }\end{array}$ & $\begin{array}{c}\text { D(SPOTR) } \\
\text { D(RCFNOV) }\end{array}$ \\
\hline Coefficient & D(SPOTR) & -0.3566 & -0.3666 & -0.4985 & -0.3678 & -0.3709 & -0.2872 \\
t-stat & & -9.58 & -13.45 & -14.80 & -11.29 & -12.19 & -8.93 \\
p-value & & 0.000 & 0.000 & 0.000 & 0.000 & 0.000 & 0.000 \\
SE & & 0.0357 & 0.0272 & 0.0337 & 0.0325 & 0.0304 & 0.0321 \\
\hline Coefficient & D(RCF) & -0.5079 & -0.7843 & -0.8617 & -0.6331 & -0.7309 & -0.4884 \\
t-stat & & -10.55 & -17.19 & -17.40 & -12.85 & -14.91 & -10.73 \\
p-value & & 0.000 & 0.000 & 0.000 & 0.000 & 0.000 & 0.000 \\
SE & & 0.0481 & 0.0456 & 0.0495 & 0.0493 & 0.0490 & 0.0455 \\
\hline Decision & & Reject $H_{0}$ & Reject $H_{0}$ & Reject $H_{0}$ & Reject $H_{0}$ & Reject $H_{0}$ & Reject $H_{0}$ \\
\hline
\end{tabular}

Negative value of coefficient which defines as Error Correction Term (ECT); based on t-stat $|\mathrm{t}|<$

$15 \%$ critical value and $p$-value is significant in $5 \%$ significant value

Further to test whether the futures market is efficient, which exhibit flow of information from futures market to spot market, simple analysis is performed to test whether in this market, there is potential arbitrage. In efficient market, non-arbitrage relationship between the two prices define by the futures prices as the unbiased predictor toward the future spot price. There are two possible conditions in coffee futures market in Indonesia. First, futures prices may higher or lower than the spot price depend on the net marginal convenience yield. Should the net marginal convenience yield be found then the futures prices may higher than spot price which reflect the "contango" and should the spot price higher that futures price than the condition is named "backwardation". Second, in efficient market, futures price and spot price moves together to avoid any arbitrage opportunity. It's expected that the two market will be highly correlated (Gupta dan Varma 2015). This topic will be later discussed in sub-chapter 4.5.

\subsection{Relationship between Local and Offshore Coffee Futures Market}

Indonesia commodity trading regulator (Bappebti) has mentioned that local spot price determination uses offshore market price as reference and hence relationship between local and offshore market is required to be performed as well to examine whether offshore market has impacted local coffee market. The results of cintegration test as shown in Table 8 also exhibit long-term relationship between spot price and offshore futures market. Furthermore, ECM presented in Table 11 and Table 12 exhibits short-term relationship between futures and spot market and the error correction term (in cointegrating equation) negative and highly significant, indicating short-term relationship between futures and spot prices. Error correction terms are significant in both futures and spot price series. This implies that in case of coffee, both spot and futures market respond to restore the equilibrium whenever there is some price discrepancy. This is in line with research performed by Malhotra and Sharma (2013) on Guar Seed which reflect the same phenomenon. 
Table 11. Analysis result of ECM of Arabica local and offshore futures market

\begin{tabular}{|c|c|c|c|c|c|c|c|}
\hline $\begin{array}{c}\text { Vector } \\
\text { Cointegration }\end{array}$ & $\begin{array}{c}\text { D(RCFJAN) } \\
\text { D(FUTRD1) }\end{array}$ & $\begin{array}{c}\text { D(RCFMAR) } \\
\text { D(FUTRD1) }\end{array}$ & $\begin{array}{c}\text { D(RCFMEI) } \\
\text { D(FUTRD1) }\end{array}$ & $\begin{array}{c}\text { D(RCFJUL) } \\
\text { D(FUTRD1) }\end{array}$ & $\begin{array}{c}\text { D(RCFSEP) } \\
\text { D(FUTRD1) }\end{array}$ & $\begin{array}{c}\text { D(RCFNOV) } \\
\text { D(FUTRD1) }\end{array}$ & $\begin{array}{c}\text { D(SPOTR) } \\
\text { D(FUTRD1) }\end{array}$ \\
\hline Coef & -0.7599 & -0.9399 & -1.0228 & -0.7958 & -0.8907 & -0.5928 & -1.3260 \\
t-stat & -14.19 & -19.22 & -19.73 & -15.29 & -16.60 & -11.78 & -16.93 \\
p-value & 0.000 & 0.000 & 0.000 & 0.000 & 0.000 & 0.000 & 0.000 \\
SE & 0.0535 & 0.0489 & 0.0518 & 0.0521 & 0.5366 & 0.0503 & 0.0783 \\
Decision & Reject $H_{0}$ & Reject $H_{0}$ & Reject $H_{0}$ & Reject $H_{0}$ & Reject $H_{0}$ & Reject $H_{0}$ & Reject $H_{0}$ \\
\hline Vector & D(RCFJAN) & D(RCFMAR) & D(RCFMEI) & D(RCFJUL) & D(RCFSEP) & D(RCFNOV) & D(SPOTR) \\
Cointegration & D(FUTRD2) & D(FUTRD2) & D(FUTRD2) & D(FUTRD2) & D(FUTRD2) & D(FUTRD2) & D(FUTRD2) \\
\hline Coef & -0.7435 & -0.9375 & -1.0361 & -0.7965 & -0.8869 & -0.5948 & -1.3214 \\
t-stat & -14.07 & -19.23 & -1986 & -15.27 & -16.76 & -11.69 & -18.45 \\
p-value & 0.000 & 0.000 & 0.000 & 0.000 & 0.000 & 0.000 & 0.000 \\
SE & 0.0528 & 0.4876 & 0.0522 & 0.5215 & 0.0529 & 0.0509 & 0.0716 \\
Decision & Reject $H_{0}$ & Reject $H_{0}$ & Reject $H_{0}$ & Reject $H_{0}$ & Reject $H_{0}$ & Reject $H_{0}$ & Reject $H_{0}$ \\
\hline
\end{tabular}

${ }^{a}$ Error Correction Term; ${ }^{b}$ negative value of coefficient; based on $t$-stat $|t|<\mid 5 \%$ critical value and $p$-value is significant in 5\% significant value

Despite the utilization of offshore futures price reference in determining local prices, which then reflect the integration of prices in one order, Indonesia crop report evidences to be very important to determine global coffee price. As reported by ICO, coffee production for crop year 2016/17 has been revised upward to 153.9 million bags, compared to our previous estimate of 151.6 million. This was mostly due to an increase in output from Indonesia, revised up from 10 million bags to 11.5 million, and a significant revision for Peru to 4.2 million bags. While production in Colombia has recovered strongly since the coffee leaf rust crisis, growth is slowly tapering off. Annual growth rates have steadily decreased from 9.7\% in 2014/15 to an estimated 3.5\% in 2016/17. However, because of adverse weather in recent months, there are concerns that the growth rate for crop in year 2017 may have to be revised further downwards (ICO 2017). In this premature coffee futures market condition, Indonesia coffee futures market has shown efficiency which confirmed the offshore price reflection to local price and strong position of Indonesia coffee production among other coffee producers.

Table 12. Analysis result of ECM of Robusta local and offshore futures market

\begin{tabular}{|c|c|c|c|c|c|c|c|}
\hline $\begin{array}{c}\text { Vector } \\
\text { Cointegration }\end{array}$ & $\begin{array}{l}\text { D(RCFJAN) } \\
\text { D(FUTRD1) }\end{array}$ & $\begin{array}{c}\text { D(RCFMAR) } \\
\text { D(FUTRD1) }\end{array}$ & $\begin{array}{l}\text { D(RCFMEI) } \\
\text { D(FUTRD1) }\end{array}$ & $\begin{array}{l}\text { D(RCFJUL) } \\
\text { D(FUTRD1) }\end{array}$ & $\begin{array}{l}\text { D(RCFSEP) } \\
\text { D(FUTRD1) }\end{array}$ & $\begin{array}{l}\text { D(RCFNOV) } \\
\text { D(FUTRD1) }\end{array}$ & $\begin{array}{c}\text { D(SPOTR) } \\
\text { D(FUTRD1) }\end{array}$ \\
\hline Coef & -0.7599 & -0.9399 & -1.0228 & -0.7958 & -0.8907 & -0.5928 & -1.3260 \\
\hline t-stat & -14.19 & -19.22 & -19.73 & -15.29 & -16.60 & -11.78 & -16.93 \\
\hline p-value & 0.000 & 0.000 & 0.000 & 0.000 & 0.000 & 0.000 & 0.000 \\
\hline $\mathrm{SE}$ & 0.0535 & 0.0489 & 0.0518 & 0.0521 & 0.5366 & 0.0503 & 0.0783 \\
\hline Decision & Reject $H_{0}$ & Reject $H_{0}$ & Reject $H_{0}$ & Reject $H_{0}$ & Reject $H_{0}$ & Reject $H_{0}$ & Reject $H_{0}$ \\
\hline $\begin{array}{c}\text { Vector } \\
\text { Cointegration }\end{array}$ & $\begin{array}{l}\text { D(RCFJAN) } \\
\text { D(FUTRD2) }\end{array}$ & $\begin{array}{c}\text { D(RCFMAR) } \\
\text { D(FUTRD2) }\end{array}$ & $\begin{array}{l}\text { D(RCFMEI) } \\
\text { D(FUTRD2) }\end{array}$ & $\begin{array}{l}\text { D(RCFJUL) } \\
\text { D(FUTRD2) }\end{array}$ & $\begin{array}{l}\text { D(RCFSEP) } \\
\text { D(FUTRD2) }\end{array}$ & $\begin{array}{l}\text { D(RCFNOV) } \\
\text { D(FUTRD2) }\end{array}$ & $\begin{array}{c}\text { D(SPOTR) } \\
\text { D(FUTRD2) }\end{array}$ \\
\hline Coef & -0.7435 & -0.9375 & -1.0361 & -0.7965 & -0.8869 & -0.5948 & -1.3214 \\
\hline t-stat & -14.07 & -19.23 & -1986 & -15.27 & -16.76 & -11.69 & -18.45 \\
\hline $\mathrm{p}$-value & 0.000 & 0.000 & 0.000 & 0.000 & 0.000 & 0.000 & 0.000 \\
\hline SE & 0.0528 & 0.4876 & 0.0522 & 0.5215 & 0.0529 & 0.0509 & 0.0716 \\
\hline Decision & Reject $H_{0}$ & Reject $H_{0}$ & Reject $H_{0}$ & Reject $H_{0}$ & Reject $H_{0}$ & Reject $H_{0}$ & Reject $H_{0}$ \\
\hline
\end{tabular}

${ }^{a}$ Error Correction Term; ${ }^{b}$ negative value of coefficient; based on $t$-stat $|t|<\mid 5 \%$ critical value and $p$-value is significant in 5\% significant value

\subsection{Arbitrage Relationship between Coffee Futures and Spot Prices}

Considering that the futures price is the price specified in an agreement (futures contract) to deliver a specified quantity of a commodity at a specific future date, whereas the spot price is the cash price for immediate purchase and sale of the commodity, we should expect a close relationship between the prices of futures contracts and spot prices. In particular, an explicit relationship between spot and futures prices can be derived from the nonarbitrage theory (Hernandez and Torero, 2010).

Following Pindyck (2001) on non-arbitrage theory, let $\gamma_{t, T}$ denote the capitalized flow of marginal convenience yield over the period t to $\mathrm{t}+\mathrm{T}$. Then, to avoid arbitrage opportunities, the following condition must hold:

$$
F_{t, T}=\left(1+r_{T}\right) P_{t}-\left(\gamma_{t, T}-k_{T}\right)
$$

where $F_{t, T}$ is the futures price of a (agricultural) commodity at time $t$ for delivery at $\mathrm{t}+\mathrm{T}, P_{t}$ is the spot price at $\mathrm{t}, r_{T}$ is the risk-free T-period interest rate, and $k_{T}$ is the per-unit cost of physical storage. To see why equation (1) must be satisfied, note that the stochastic return of holding a unit of the agricultural commodity from $\mathrm{t}$ to $\mathrm{t}+\mathrm{T}$ is equal to $\left(P_{t+T}-P_{t}\right)+\gamma_{t, T}-k_{T}$. If a farmer also sells a futures contract at $t$ (that is, takes a short position), the return of this future contract is $F_{t, T}-P_{t+T}$. So the farmer's total non-stochastic return at $\mathrm{T}$ is equal to $F_{t, T}-P_{t}+\gamma_{t, T}-k_{T}$. Then, the non-arbitrage condition requires this total return to equal the risk-free rate times the price of the commodity at $t$, that is, $r_{T}, P_{t}$ from which equation (1) follows. Further, Pyndick mentioned that 
two implications can be derived from equation (1). First, the futures price could be greater or less than the spot price, depending on the net (of storage costs) marginal convenience yield $\gamma_{t, T}-k_{T}$. If the net marginal convenience yield is positive and large, the spot price will exceed the futures price (futures market exhibits strong backwardation); however, if the net marginal convenience yield is negative, the spot price will be less than the futures price (the futures market is in contango). Second, spot and futures prices should move together across time to avoid arbitrage opportunities. That is, we expect price movements in spot and futures markets to be correlated. To avoid arbitrage, the above condition must be satisfied.

Provided that futures markets are generally considered to perform two major roles in commodity marketsa risk-transfer role and, in particular, an informative or price discovery role - we might be tempted to assume that futures markets dominate spot markets. The risk-transfer role results from the fact that a futures market is a place where risks are reallocated between hedgers (producers) and speculators. Producers are then willing to compensate speculators for sharing the risks inherent in their productive activity. Futures prices also transmit information to all economic agents, especially to uninformed producers who, in turn, may base their supply decisions on the futures price. It can also be argued that physical traders use futures prices as a reference to price their commodities due to the greater transparency and (often) greater liquidity of commodity futures over physical commodities.

In a perfect market where there are 1) no transaction cost; 2) no limitation of short of the commodity; 3) no restriction on the use of the proceed from such a sale; 4) no taxes; 5) no constrain on borrowing; 6) non stochastic interest rate and dividend, the following equilibrium relationship exist between futures and spot market:

$$
F_{t, T}=S_{t} e^{(r+g-q)(T-t)}
$$

where $F_{t, T}$ is the futures price at time $\mathrm{t}$ for delivery at time $\mathrm{T}, S_{t}$ is the spot price at time $\mathrm{t}, \mathrm{r}$ is the annualized interest rate, $\mathrm{T}-\mathrm{t}$ is the time to maturity, $\mathrm{g}$ is the annualized storage cost as a percentage of the spot price, and $\mathrm{q}$ is the dividend yield or risk free rate. If market is perfect and this equality is not satisfied an arbitrage opportunity exist. For instant, if $F_{t, T}>S_{t} e^{(r+g-q)(T-t)}$ an arbitrageur would buy the underlying instrument in the spot market adnd carry it to maturity while silmulatenously selling the futures contract. These action would drive futures prices and spot prices back into their relationship. If the aforementioned equation were always true, the futures price would not supply any additional information about current or future spot prices which would be learned simply by observing the current spot price. In other words, futures prices would be informationally redundant (Canter, 1999).

Test toward the coffee futures and spot price historical information is suspected to have the arbitrage condition and therefore have arbitrage opportunity that may benefit the arbitrageur and speculator from the futures market position. Figure 3 exhibits Arabica coffee price have strong contango whereby the spot price is lower than the futures price. The Robusta coffee price also exhibits the similar pattern. Other commodity may show different movement e.g for corn as Hernandez and Torero (2010) research that corn futures markets exhibit strong backwardation, i.e. the spot price is on average higher than the price of the nearby futures contract.

Agricultural futures markets or exchanges primarily function as a mechanism for discovering prices and managing market risks associated with price variability and stock holding. Agriculture futures markets may be classified as efficient if they perform these primarily functions efficiently. For these markets to be efficient, we expect spot and futures prices to move together across time to avoid arbitrage opportunities or price movements in spot and futures markets are expected to be correlated - i.e., information on spot and futures prices must be strongly linked. However, as in any market, inefficiencies and failures will and do occur. In particular, there have been price volatility in many agricultural commodities since 2007 and the public, media and many economists question if the futures markets have been efficient in the midst of the price volatility (Holloway, 2012).
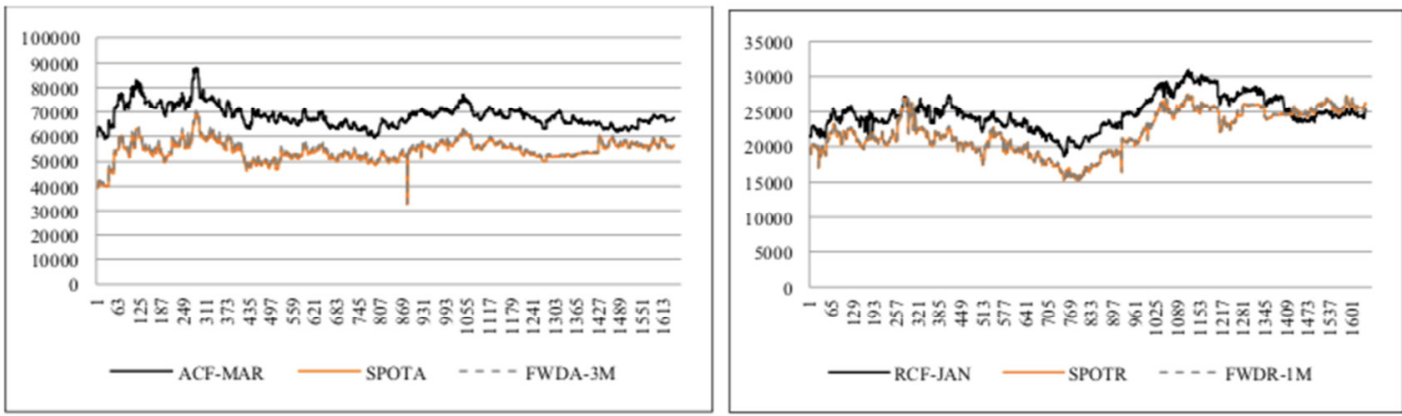

Figure 3. Arbitrage of Arabica and Robusta futures and spot market

We examine this hypothesis using the sign of the futures basis (futures price minus spot price) which 
according to Canter (1999) this ideally as a proxy for the current level of inventory. This test has been performed refer to Fama and French (1987) who have used the phrase the "theory of storage" to refer to the theory behind the cost of carry formula inclusive of a convenience yield. A positive basis (called a contango market) indicates that supplies are ample, whereas a negative basis (called backwardation) indicates that there is a shortage of the commodity.

$$
\text { Basis }_{t}=\frac{F_{t, T}}{S_{t}}=e^{(r+g-q)(T-t)}
$$

where $F_{t, T}$ is the futures price at time $\mathrm{t}$ for delivery at time $\mathrm{T}, \mathrm{S}$, is the spot price at time $\mathrm{t}, \mathrm{r}$ is an annualized interest rate, $\mathrm{T}-\mathrm{t}$ is the time to maturity, $\mathrm{g}$ is an annualized storage cost as a percentage of the spot price, and $\mathrm{q}$ is a dividend yield (for stock index contracts) or a risk free rate on a foreign currency (for currency contracts. If markets are perfect and this equality is not satisfied, there exists an arbitrage opportunity. For instance, if the basis is greater than $\mathrm{e}(\mathrm{r}+\mathrm{g} *)<\mathrm{r}-\mathrm{t})$, the cost of carry then an arbitrageur will buy the commodity in the spot market and carry it to maturity while simultaneously selling the futures contract.

Indonesia market shows contango condition all the time which reflects the futures price were always higher compare to spot prices. Other commodity market may exhibit different behavior. Indonesia contango phenomenon could also be the impact of suspected role of speculator as also communicated by Kumar and Pandey (2013), contango condition implies where long hedgers paying a risk premium to short speculators. Again, Canter (1999) mentioned that the low cost of participating in and short selling in futures markets improves the price discovery process because it attracts more market participants (hedgers and speculators). In premature market condition, Indonesia has shown an efficient market condition which indicated by cointegration between futures and spot market. This is due to speculator plays important role connecting the two markets. However, several researchers Brenner and Kroner (1995) and Kellard (2002) caution that commodity markets might not be efficient in the long run since futures and spot may not be cointegrated due to several counts, namely, arbitrage. In this stage, Indonesia market shows the otherwise in which there is an arbitrage potential and however the two market is cointegrated indicates the efficient market.

\section{Managerial Implication}

All market participants and also other relevant stakeholders shall have the same access to the price information both spot and futures prices. Should all parties in the whole coffee supply chain, especially farmer, equipped by price information, they will have selling option which not directly sell to collector trader however may sell coffee to the nearest spot market especially when the futures price is the unbiased predictor of the spot prices which then benefit farmer in optimizing their income by choosing the market they wish to sell the coffee.

The findings in this study are useful for various stakeholders active in agricultural commodities markets especially coffee such as producers, traders and regulators as policy makers. The cointegration of the two markets which reflects the efficient market condition is beneficial to all market participants to decide the hedging decision. Although there are several limitations in using cointegration test and Error-Correction Model (ECM) in analyzing efficiency in commodity futures markets, these techniques provide useful understanding of futures trading system in Indonesia and may identify the flow of information from Indonesia futures market to spot market for both Arabica and Robusta.

The cointegration results imply that it may be possible to hedge whether in the long term or short term in the futures market in order to reduce the price risks. Flow of information discovered in the studies may be useful to both traders and speculators and there is also an arbitrage opportunity between the spot and futures contracts.

\section{Conclusion}

The results suggest that each price series is non-stationary in levels but stationary in first difference. This indicates that coffee spot and future prices are integrated of order one. Secondly, the spot and futures prices are cointegrated. This implies that coffee futures and spot prices are tied together in a long-run equilibrium relationship. Finally, ECM is used to study the short-run dynamics relationship between spot and futures prices. The result shows that changes in future prices do effectively influence changes in the spot price especially in local price behaviour. This provides further evidence that future prices possess the price discovery function, therefore future prices may be used by producers and traders as the relevant price signal for decision making purposes. Unique condition for Indonesia market which shows efficient market although there is arbitrage potential and may however beneficial to hedgers, speculators and arbitrageurs in connecting the two market. Local futures market and spot market also exhibit long term relationship with offshore futures markets. This might be occurred due to the offshore futures price is still used as local price reference.

\section{References}

Ajao, Y. (2012). Performance Prediction of Commodity Prices using Foreign Exchange Futures. Walden (US): Walden University 
Ali, J., Gupta, K.B. (2011). Efficiency in Agricultural Commodity Futures Markets in India: Evidence from Cointegration and Causality Tests. Agricultural Finance Review, 71(2), 162-178.

Arifin, B. (2010). Global Sustainability Regulation and Coffee Supply Chains in Lampung Province, Indonesia. Asian Journal of Agriculture and Development, 7(2), 67- 89.

[Bappebti] Indonesia Commodity Futures Supervisory Body. (2015). Robusta coffee price analysis third week of June 2015. Jakarta (ID), Bappebti.

[Bappebti] Indonesia Commodity Futures Supervisory Body. 2014. Analisis Harga Kopi Robusta Pekan Keempat May 2014. Jakarta (ID): Bappebti

Bose, S. (2007). Commodity futures market in India: a study of trends in the notional multi- commodity indices. Money \& Finance. ICRA Bulletin, 3(3): 125-158

Brennan, M. (1958). The supply of storage”. American Economic Review, 48, 50-72.

Brenner, R.J., Kroner K.F. (1995). Arbitrage, co-integration and testing the unbiasedness of hypothesis in financial markets. Journal of Financial and Quantitative Analysis, 30(1), 23-42.

Canter, C.A. (1999). Commodity Futures Markets: A Survey. The Australian Journal of Agricultural and Resource Economics, 43(2), 209-247.

Chen, A.S., Lin, J.W. (2004). Cointegration and detectable linear and nonlinear causality: analysis using the London metal exchange lead contract. Applied Economics, 36(11), 1157-1167.

Dewi, A., Siregar, H. \& Manurung, A.H. (2011). Analisis Kontrak Berjangka Olein di Bursa Berjangka Jakarta. Jurnal Manajemen dan Agribisnis, 8(1), 1-9.

Dickey, D., Fuller, W.A. (1979). Distribution of the estimators for time series regressions with unit roots. Journal of the American Statistical Association, 74, 427-431.

[DIRJENBUN] Forestry Directorate General. (2016). Statistik Perkebunan Indonesia: Kopi. Jakarta (ID), DIRJENBUN.

Engle, R.F., Granger, C.W.J. (1987). Co-integration and error correction: Representation, estimation, and testing. Econometrica (55), 251-276. doi:10.2307/ 1913236.

Fama, E.F. (1970). Efficient Capital Markets: A Review of Theory and Empirical Work. Journal of Finance, 25, $383-423$

Fama, E., French K. (1987). Commodity Futures Prices: Some Evidence on Forecast Power, Premiums, and the Theory of Storage. Journal of Business, 60, 55-73

Fortenbery, T.R., Zapata, H.O (1997). An Evaluation of Price Linkages Between Futures and Cash Markets for Cheddar Cheese. Journal of Futures Markets, 17(3), 279-301.

Fortenbery, R., Zapata, H. (2004), "Developed Speculation and Underdeveloped Markets - The Role of Futures Trading on Export Prices in Less Develop Countries. European Review of Agricultural Economics, 31, 451471.

Ghosh, A. (1993). Hedging with Stock Index Futures: Estimation and Forecasting with Error Correction Model. Journal of Futures Market, 13(7), 743-752.

Granger, C.W.J. (1986). Developments in the Study of Cointegrated Economic Variables. Oxford Bulletin of Economics and Statistics, 48 (3), 213-228.

Gupta, A., Varma, P. (2015). Impact of Futures Trading on Spot Markets: An Empirical Analysis of Rubber in India. Eastern Economic Journal, 42(4210), 373-386

Hernandez, M., Torero M. (2010). Examining the Dynamic Relationship between Spot and Future Prices of Agricultural Commodities. IFPRI Discussion Paper. https:/core.ac.uk/download/pdf/6270326.pdf (July 30, 2017)

Holloway, J. (2012). The Role of Speculators in Recent Price Volatility in Wheat Futures Markets, PhD Thesis, Arkansas (US): Arkansas State University.

[ICO] International Coffee Organization. 2017. Coffee Market Report. July 2017.

Jian, Y., Leatham, D.J. (1999). Price Discovery in Wheat Futures Markets. Journal of Agricultural and Applied Economic, (31)2, 359-370.

Kaldor, N. (1939). Speculation and economic stability. Review of Economic Studies, 7, 1-27.

Kargbo, J. (2005). Impacts of Monetary and Macroeconomic Factors on Food Prices in West Africa. Agrekon, 44(2), 205-224.

Kebede, Y. (1993). Causality and Efficiency in the Coffee Futures Market. Journal of International Food and Agribusiness Marketing, 5, 55-71.

Kellard, N. (2002). Evaluating commodity market efficiency: are co-integration tests appropriate. (unpublished). London: London Guildhall University

Kumar, S. (2004). Price Discovery and Market Efficiency: Evidence from Agricultural Commodities Futures Markets. South Asian Journal of Management, 33(2), 32-47.

Kumar, B., Pandey, A. (2013). Market Efficiency in Indian Commodity Futures Markets. Journal of Indian Business Research, 5(2), 101-121. 
Kurosaki, T. (1998). Risk and household behavior in Pakistan's agriculture. IDE Occasional Papers Series No. 34. Institute of Developing Economies.

Lence, S.H. (2009). Do futures benefit farmers?. American Journal of Agricultural Economics, 91(1): 154-167

Lien, D. (1996), The Effect of the Cointegrating Relationship on Futures Hedging: A Note. Journal of Futures Markets, 16(7), 773-780.

Lien, D., Luo, X. (1994). Multi-Period Hedging in the Presence of Conditional Heteroskedasticity". The Journal of Futures Market, 14(8), 927-956.

Lien, D., Tse, Y.K. (2000), "Some recent development in futures hedging". Working Paper. San Antonio TX (US): University of Texas

Mahalik, M.K., Debashis, A \& Babu, M.S. (2014). Price Discovery and Volatility Spillovers in Futures and Spot Commodity markets. Journal of Advances in Management Research, 11(2), 211-226

Mattos, F \& Garcia, P. (2004). Price Discovery in Thinly Traded Markets: Cash and Futures Relationships in Brazilian Agricultural Futures Markets. paper presented at the NCR-134 Conference on Applied Commodity Price Analysis, Forecasting, and Market Risk Management held on April 19-20, St. Louis, Missouri.

Mckenzie, A \& Holt, M. (1998). Market Efficiency in Agricultural Futures Markets. 1998 American Agricultural Economics Association Annual Meeting in Salt Lake City.

Mohan, S \& Love, J. (2004). Coffee futures: role in reducing coffee producers' price risk. Journal of International Development, 16, 983-1002

Pindyck, R. S. (2001). The dynamics of commodity spot and futures markets: A primer. Energy Journal, 22 (3), $1-29$.

Pertiwi D. (2016). Pengujian Efisiensi Pasar dan Tingkat Konvergensi Harga Komoditas Kopi Arabika dan Kopi Robusta (Studi Kasus pada Pasar Komoditas Berjangka di Indonesia). Jurnal Manajemen Pemasaran,. 9(2), 43-53

Piot-Lepetit I. \& M'barek R. (2011). Methods to Analyse Agricultural Commodity Price Volatility. New York (US): Springer.

Putri, M.A., Fariyanti, A \& Kusnadi, N. (2013). Struktur dan Integrasi Pasar Kopi Arabika Gayo di Kabupaten Aceh Tengah dan Bener Meriah".Buletin RISTI, 4(1), 47-54.

Radha, K \& Balakrishnan, K. (2017). The Role of Commodity Futures in Risk Management: A Study of Select Agricultural Commodities. The IUP Journal of Financial Risk Management, 14(14), 7-29.

Revoredo-Giha, C \& Zuppiroli, M. (2013). Commodity Futures Markets: Are They an Effective Price Risk Management Tool for the European Wheat Supply Chain?". Journal of Bio-based and Applied Economics, 2(3), 237-255.

Sarris, A., Conforti, P \& Prakash, A. (2011). Using Futures and Options to Manage Price Volatility in Food Imports: Theory. In Prakash A. (ed.). Safeguarding food security in volatile global markets. Rome (IT): Food and Agriculture Organization of the United Nations.

Schnepf, R. (2006). Price Determination in Agricultural Commodity Markets: A Primer. Congressional Research Service - Report for Congress, 39

Sharma, D.K \& Malholtra, M. (2013). Impact of Futures Trading on Volatility of Spot Market-A Case of Guar Seed. Journal of Agricultural Finance Review, 75(3), 416-431.

Telser, L. (1958). Futures trading and the storage of cotton and wheat. Journal of Political Economy, 66(3), 233255

Walker, T.S \& Ryan J.G. (1990). Village and Household Economics in India's Semi-arid Tropics. Johns Hopkins University Press, Baltimore, MA.

Wang, H.H \& Ke, B. (2005). Efficiency Tests of Agricultural Commodity Futures Markets in China. The Australian Journal of Agricultural and Resource Economics, 49, 125-141.

Wibowo B. 2017. Hedging Ratio Measurement Methods and Hedging Effectiveness in Jakarta Futures Exchanges. Jurnal Ekonomi Pembangunan, 18(1), 118-130.

Working, H. (1948). Theory of the Inverse Carrying Charge in Futures Markets. Journal of Farm Economics, $30(1), 1-28$ 